\title{
MAKING SENSE OF COMMERCIAL COMMON SENSE
}

\author{
Suzanne Robertson $Q C^{*}$
}

\begin{abstract}
The article examines the use of "commercial common sense" in the interpretation of commercial contracts. It reviews the origins of the test of commercial common sense and traces the application of the test in relatively recent New Zealand and United Kingdom appellate decisions. The author's contention is that the test is only properly applied when a court asks itself which of the interpretations put forward by the parties is most consistent with the contracting parties' mutual commercial purpose. The test is not properly applied when a court prefers one interpretation to another simply because it is the court's view that the alternative would mean one party made a particularly bad bargain.
\end{abstract}

\section{INTRODUCTION}

The purpose of interpretation is to identify what the parties have agreed, not what the court thinks that they should have agreed. ${ }^{1}$

A welcome reminder to be wary about interpreting commercial agreements according to commercial common sense has been given by the United Kingdom Supreme Court. In the words of Lord Neuberger SCJ: ${ }^{2}$

The mere fact that a contractual arrangement, if interpreted according to its natural language, has worked out badly, or even disastrously, for one of the parties is not a reason for departing from the natural language. Commercial common sense is only relevant to the extent of how matters would or could have been perceived by the parties, or by reasonable people in the position of the parties, as at the date that the contract was made.

* Suzanne Robertson is a Queen's Counsel at Bankside Chambers. She provides advice and advocacy in commercial and civil disputes, including breach of contract disputes.

1 Arnold v Britton [2015] UKSC 36, [2015] AC 1619 at [20] per Lord Neuberger SCJ (with whom Lord Sumption and Lord Hughes SCJJ agreed).

2 At [19]. 
The test of commercial common sense is only properly applied when the common sense is judged in the light of the objectively ascertained purposes of both parties to the agreement at the time the agreement was made. The test is not properly applied when a court prefers one interpretation over another simply because the alternative would mean one party made a particularly bad bargain.

It is inherent in the nature of a bad bargain that it is likely to be contrary to commercial common sense for one party to the bargain. However, for the other party to the bargain, it is likely to be the epitome of commercial common sense. It is only when an agreement is not consistent with the commercial objective both parties are trying to achieve that it will be contrary to commercial common sense for both parties. This is the only way that commercial common sense can be said to be "common".

This article discusses the origin of the concept of commercial common sense and its use in recent New Zealand and United Kingdom decisions. The notions of whether an agreement is consistent with the parties' overall commercial purpose and whether a party has made a bad bargain can overlap to a degree. However, it is important to recognise the difference and to be wary of arguments or decisions based on the latter. Recent decisions in both countries suggest the courts are less inclined to decide between competing contractual interpretations by attempting to identify the most commercially sensible conclusion.

\section{EVOLUTION OF COMMERCIAL COMMON SENSE}

The ultimate objective in a contractual interpretation dispute is to establish the meaning the parties intended their words to bear. ${ }^{3}$ This exercise has been described as one in which the court: ${ }^{4}$

... must consider the language used and ascertain what a reasonable person, that is a person who has all the background knowledge which would reasonably have been available to the parties in the situation in which they were at the time of the contract, would have understood the parties to have meant. In doing so, the Court must have regard to all the relevant surrounding circumstances.

If there are two possible interpretations put forward, the court is entitled to prefer the interpretation that is consistent with business common sense and to reject the other. ${ }^{5}$ However, determining that one interpretation is more consistent with business common sense than another is far more easily said than done.

The genesis of the concept of business common sense as an aid to interpretation of contracts is most often attributed to the judgment of Lord Diplock in Antaios Compania Naviera SA $v$ Salen

3 Vector Gas Ltd v Bay of Plenty Energy Ltd [2010] NZSC 5, [2010] 2 NZLR 444 at [19].

4 Rainy Sky SA v Kookmin Bank [2011] UKSC 50, [2011] 1 WLR 2900 at [21].

5 At [21]. 
Rederierna $A B{ }^{6}$ The substantive issue between the parties in Antaios was the interpretation of a Charter-party. However, the case reached the House of Lords by way of an appeal from a refusal to allow leave to appeal to the High Court. Therefore, Lord Diplock's judgment is almost wholly concerned with the issue of when leave to appeal arbitral awards ought to be granted. The comment on interpretation of the Charter-party was dictum only.

Lord Diplock referred to a particular passage in the arbitrator's reasoning: ${ }^{7}$

We always return to the point that the owners' construction is wholly unreasonable, totally uncommercial and in total contradiction to the whole purpose of the NYPE time charter form. The owners relied on what they said was 'the literal meaning of the words in the clause.' We would say that if necessary, in a situation such as this, a purposive construction should be given to the clause so as not to defeat the commercial purpose of the contract.

The arbitrator's description of the owner's construction as 'totally uncommercial' was because it was in total contradiction to the whole purpose of the parties' contract.

About this passage Lord Diplock said: ${ }^{8}$

While deprecating the extension of the use of the expression "purposive construction" from the interpretation of statutes to the interpretation of private contracts, I agree with the passage I have cited from the arbitrators' award and I take this opportunity of re-stating that if detailed semantic and syntactical analysis of words in a commercial contract is going to lead to a conclusion that flouts business commonsense, it must be made to yield to business commonsense.

Lord Diplock's dictum became immortalised for contract lawyers by its inclusion in Lord Hoffmann's summary of principles by which contractual documents are to be construed in Investors Compensation Scheme Ltd v West Bromwich Building Society. ${ }^{9}$ Lord Hoffmann's five principles have become the touchstone for interpretation of contracts and admissibility of evidence in contractual interpretation disputes. ${ }^{10}$ The fifth principle concerned commercial common sense: ${ }^{11}$

(5) The "rule" that words should be given the "natural and ordinary meaning" reflects the commonsense propositions that we do not easily accept that people have made linguistic

6 Antaios Compania Naviera SA v Salen Rederierna AB [1985] AC 191 (HL).

7 At $200-201$

8 At 201.

9 Investors Compensation Scheme Ltd v West Bromwich Building Society [1998] 1 WLR 896 (HL) at 913.

10 More recently there has been obiter comment casting some doubt on Lord Hoffmann's fifth principle: Marley $v$ Rawlings [2014] UKSC 2, [2015] AC 129 at [37]-[40]. See also David McLauchlan "The lingering confusion and uncertainty in the law of contract interpretation" [2015] LMCLQ 406 at 413.

11 Investors Compensation Scheme, above n 9, at 913. 
mistakes, particularly in formal documents. On the other hand if one would nevertheless conclude from the background that something must have gone wrong with the language, the law does not require Judges to attribute to the parties an intention which they plainly could not have had.

Investors Compensation Scheme concerned the interpretation of a form for making a claim for compensation with the Investors Compensation Scheme (ICS). The scheme had been set up under the Financial Services Act 1986 (UK) to provide a compensation fund for people with unsatisfied claims against their financial advisors. As a condition of making a claim on the fund, the claimants were required to assign to ICS certain rights they had in relation to their claim against their financial advisor. The question of interpretation concerned the exact rights that were assigned to ICS.

As well as considering the wording of the claim form, Lord Hoffmann (who gave the majority judgment) looked at the wording of the Financial Services Act, the rules governing the compensation scheme and an explanatory note, which was provided by ICS to potential claimants against the fund with the claim form. ${ }^{12}$

Having considered all of these extrinsic facts, which comprised the background to the claim form, his Lordship concluded that the correct interpretation was that more, rather than fewer, rights had been assigned and that the form intended a narrow exception for the assignment purely to address a technical legal point. In reaching this conclusion Lord Hoffmann agreed with the first instance Judge, Evans-Lombe J. Justice Evans-Lombe had accepted that the alternative interpretation was open on a plain reading of the words but said that such interpretation was contrary to the "demonstrable purpose of the parties in entering into the claim forms". ${ }^{13}$ Both the Court of Appeal and the Minority Judge in the House of Lords, Lord Lloyd, preferred the natural meaning of the words and did not regard them as leading to a commercially "ridiculous", "extraordinary" or "unreasonable" construction. ${ }^{14}$

Two points can be made about the exercise Lord Hoffmann carried out to ascertain the construction of the form most consistent with "business common sense". First, his Lordship examined other objective documents which could shed light on what the overall purpose of the parties was, such as the Financial Services Act under which the scheme was set up and the explanatory note given to the investors at the same time as the claim form. These are objectively ascertainable extrinsic facts which shed light on what the parties understood they were achieving. Second, any mention of whether it would have made more sense for one or other party to agree to a particular interpretation is absent from the judgment.

12 Investors Compensation Scheme, above n 9, at 913.

13 At 901

14 At 905 . 
Lord Hoffmann's yardstick of commercial common sense was applied by finding the interpretation considered to be most consistent with the commercial purpose of the parties' agreement. He did not consider what the different consequences of the alternative interpretations might be for each party. Rather, he focused on what construction was most consistent with the Court's understanding of what the parties were attempting to achieve.

Lord Hoffmann's five principles for interpretation of contracts were cemented into New Zealand law in Boat Park Ltd v Hutchinson. ${ }^{15}$ The parties had entered into an agreement for the sale and purchase of land which included a vendor mortgage. The agreement for sale and purchase limited the vendor mortgage to 75 per cent of a "registered valuer's valuation of the property", which was to be obtained "by and at the expense of the purchaser". The purchaser produced a valuation which was over twice the purchase price and which had been carried out on the basis that a hypothetical subdivision was successfully carried out. The vendor obtained a valuation based on current market value of the land in its existing state, which was similar to the purchase price.

Of the alternative interpretations proffered to the Court of Appeal in Boat Park, there surely can have been little doubt that the vendor's interpretation was the correct interpretation. The Court adopted this interpretation with little difficulty. The position and behaviour of the appellants seems to have been somewhat opportunistic. As the Courtsaid "[a]ny other conclusion would defy both common sense and valuation theory and practice." 16

As the correct interpretation could be arrived at so easily, the question before the Court required little discussion of principles of interpretation. The Court of Appeal reiterated in full Lord Hoffmann's five principles of interpretation and applied those principles to reject the purchaser's valuation.

The next landmark decision concerning commercial common sense in interpretation of contracts was the House of Lords decision in Chartbrook Ltd v Persimmon Homes Ltd.${ }^{17}$ It also concerned an agreement for sale and purchase of land. In this case all parties were aware the land was going to be developed. The vendors were not to be paid for the land until sometime after the development had been completed. The purchase price was to be calculated as a payment for total land value (the calculation of which was set out in the contract) and a balancing payment defined as the "Additional Residential Payment" (ARP). The issue before the Court was the correct interpretation of the contractual definition of the ARP.

15 Boat Park Ltd v Hutchinson [1999] 2 NZLR 74 (CA).

16 At 85 .

17 Chartbrook Ltd v Persimmon Homes Ltd [2009] UKHL 38, [2009] AC 1101. 
The first instance Judge and the majority of the Court of Appeal adopted an interpretation based on the syntax used in the definition of ARP. ${ }^{18}$ Lord Justice Lawrence Collins, dissenting in the Court of Appeal, and the House of Lords adopted the alternative interpretation having been persuaded that to interpret the definition of ARP in accordance with ordinary rules of syntax made no commercial sense.

Part of what persuaded the House of Lords to adopt the alternative construction was the other terms of the contract and the particular words (as opposed to the syntax) used. In particular, the interpretation suggested by the appellant recognised an element of contingency about the payment of the ARP and the respondent's did not. The words used and other terms of the contract supported the concept of a contingent payment.

Lord Hoffmann recognised the uncertainty that can be introduced through judges interpreting contracts in order to be consistent with commercial common sense. He said: ${ }^{19}$

It is, I am afraid, not unusual that an interpretation which does not strike one person as sufficiently irrational to justify a conclusion that there has been a linguistic mistake will seem commercially absurd to another...

His Lordship also recognised that a bad bargain in the eyes of the court, on its own, does not constitute commercial common sense. He said: ${ }^{20}$

It is of course true that the fact that a contract may appear to be unduly favourable to one of the parties is not a sufficient reason for supposing that it does not mean what it says. The reasonable addressee of the instrument has not been privy to the negotiations and cannot tell whether a provision favourable to one side was not in exchange for some concession elsewhere or simply a bad bargain. But the striking feature of this case is not merely that the provisions as interpreted by the Judge and the Court of Appeal are favourable to Chartbrook. It is that they make the structure and language of the various provisions of Schedule 6 appear arbitrary and irrational, when it is possible for the concepts employed by the parties ... to be combined in a rational way.

What made commercial sense was again determined by reference to the overall purpose and other provisions of the contract. One interpretation was not found to be more commercially sensible because the provisions of the contract were more favourable to one party than the other.

18 Chartbrook Ltd v Persimmon Homes Ltd [2007] EWHC 409 (Ch); and Chartbrook Ltd v Persimmon Homes Ltd [2008] EWCA Civ 183.

19 Chartbrook, above n 17, at [15].

20 At [20]. 


\section{VECTOR GAS}

The well-known New Zealand Supreme Court decision of Vector Gas Ltd v Bay of Plenty Energy Ltd has attracted substantial comment in relation to admissibility of extrinsic evidence, particularly evidence of prior negotiations, in disputes over the proper interpretation of written contracts. ${ }^{21}$ It is also noteworthy because some of the judges appear to have adopted the reasoning of discounting an interpretation put forward by one party which appeared "unduly favourable to one of the parties".22

The facts can be restated quite briefly. A dispute arose over Vector Gas's obligation to continue supplying gas to Bay of Plenty Energy under an agreement between the parties. Bay of Plenty Energy said it was going to refer the dispute to the court and the parties negotiated an agreement to govern supply pending resolution of that dispute. If the court ultimately found, as contended by Vector Gas, that it was entitled to terminate supply, Bay of Plenty Energy agreed to pay the difference between the price in the terminated agreement to supply and $\$ 6.50$ per GJ plus interest for gas supplied in the interim.

The Supreme Court and all the courts below agreed that Vector Gas's termination of supply was lawful and therefore Bay of Plenty Energy became liable to pay for the gas supplied according to the interim agreement reached. The parties disagreed about whether the "\$6.50 per GJ" did or did not include transmission costs.

The contract before the court in Vector Gas differed in a significant way from those before the courts in the cases discussed above. The agreement before the court had been reached through an exchange of correspondence. There was no formal written contract recording the parties' agreement. It seems at least possible, if not probable, that had the parties decided to draw up a formal written agreement, in the process of drafting that agreement, they would have expressly addressed the issue of transmission costs. This would have avoided the need for the court to reach a conclusion as to what the parties had intended from their correspondence.

The Supreme Court did not explicitly refer to the informal nature of the agreement. In the author's view, this is a relevant factor. Lord Hoffmann's fifth principle of contractual interpretation in Investors Compensation Scheme is: ${ }^{23}$

The "rule" that words should be given their "natural and ordinary meaning" reflects the common sense proposition that we do not easily accept that people have made linguistic mistakes, particularly in

formal documents.

21 Vector Gas Ltd v Bay of Plenty Energy Ltd [2010] NZSC 5, [2010] 2 NZLR 444.

22 Contrary to Lord Hoffmann's caution in Chartbrook, above n 17, at [20].

23 Investors Compensation Scheme, above n 9, at 913 (emphasis added). 
Further, the original statement by Lord Diplock in Antaios was: ${ }^{24}$

If detailed semantic and syntactical analysis of words in a commercial contract is going to lead to a conclusion that flouts business commonsense, it must be made to yield to business commonsense.

It is logical that greater weight should be placed on the actual words used where parties have undertaken the exercise of recording their agreement in a formal commercial document. Less precision could be expected in the expression of an agreement recorded in correspondence written by litigation partners.

At first instance the High Court decided that "\$6.50 per GJ" did not include transmission costs. $^{25}$ The Court decided this partly by reference to earlier correspondence suggesting that measuring and transportation costs were put to one side while the parties focused simply on the price of the gas itself.

The evidence also showed that at the relevant time the market price of the gas was in the vicinity of $\$ 6.50$ per GJ plus transmission costs. Therefore the Court also considered that it was "contrary to business common sense" to suggest that Vector Gas would have agreed to supply at $\$ 6.50$ per GJ inclusive of transportation and measuring costs. ${ }^{26}$ It is this reasoning that is dangerously close to the proposition that an interpretation which results in a bad bargain for one party ought to be rejected.

The Court of Appeal overturned the High Court, relying on the plain meaning of the words as recorded in the final piece of correspondence - "\$6.50 per GJ". ${ }^{27}$ The Court considered it unnecessary to refer to earlier correspondence and that any implausibility of Vector Gas agreeing to supply at this price could be explained by a desire to protect its reputation by achieving a private agreement on the matter.

The Supreme Court restored the decision of the High Court and found that the $\$ 6.50$ per GJ was exclusive of transmission costs. Each of the members of the Court gave a separate judgment with individual reasoning. Crucial to the difference in opinion from the Court of Appeal was the Supreme Court's view that the earlier correspondence, in particular the letter of 28 September 2004, made it clear that the parties at that time put the question of transmission costs to one side and focused solely on the price for the gas alone. This reflected the standard exercise of ascertaining what a reasonable person would have understood the parties to have meant by the language they have used.

24 Antaios, above n 6, at 201 (emphasis added).

25 Vector Gas Ltd v Bay of Plenty Energy Ltd HC Auckland CIV-2004-485-2287, 3 August 2007.

26 At [128]-[129].

27 Bay of Plenty Electricity Ltd v Vector Gas Ltd [2008] NZCA 338. 
The relevant reasonable person is one who has the relevant background knowledge that would reasonably have been available to the parties at the time they entered into the contract. ${ }^{28}$

The alternative reasoning adopted by most members of the Court is more problematic. The notion that a bad bargain (for one party) could not be the correct interpretation because it would not be in accordance with commercial common sense is found in almost all of the judgments to a greater or lesser extent, with the exception of the judgment of Gault J. For example, Blanchard J said: ${ }^{29}$

[Bay of Plenty Energy's] suggested interpretation of the interim agreement, which was in effect a proxy or substitute for an interim order of the Court, is thus exposed as commercially absurd. There is no reason why [Vector Gas] would have elected to enter into an interim agreement on such an extremely unfavourable basis when allowing the matter to go to Court would have produced a much more favourable outcome for it.

And further: ${ }^{30}$

No party in its position, acting rationally, would ever in these circumstances have agreed to give up recovery from BOPE of the transmission costs or, putting it another way, would have agreed to discount the current market price by the equivalent of the transmission costs.

Justice Wilson said: ${ }^{31}$

This was more than a bad bargain for [Vector Gas]. It would have defied commercial sense for [Vector Gas] to have contracted on those terms ...

Justice Tipping also considered it: ${ }^{32}$

... inherently most unlikely that [Vector Gas] would have been willing to enter into any interim arrangement on a basis which was less favourable to it than an undertaking as to damages would have been.

Interpreting a contract in a certain way because otherwise it would be unfavourable to one party is fraught with danger. It leads to difficult and uncertain questions about the extent of bad bargain required before a court will accept or reject a particular interpretation. A court cannot be certain it has before it all the reasons that influenced a party to agree to particular provisions. It is also not how the touchstone of commercial common sense is meant to be applied.

28 Vector Gas, above n 21, at [61].

29 At [8].

30 At [10].

31 At [137].

32 At [39]. 
As the English and Welsh Court of Appeal said in Bank of Nova Scotia v Hellenic Mutual War Risk Assoc (Bermuda) Ltd: ${ }^{33}$

It is nonetheless important, in attributing a purpose to a commercial transaction, to be sure that it is the purpose of both parties and not just one. If the purpose of the transaction is seen through the eyes of one party only an unbalanced view of the transaction may result. Many contracts represent a compromise between what one party wishes to obtain and the other is willing to give.

The concern with the Supreme Court's judgment in Vector Gas is not the outcome. The outcome could have been reached by applying conventional principles on the interpretation of contracts. The concern is the reasoning in relation to the concept of commercial common sense.

The commercial common sense test requires a court to ascertain what interpretation is more likely to be consistent with the purpose of both parties to the transaction. An interpretation that is contrary to that mutual purpose is contrary to commercial common sense. An interpretation is not contrary to commercial common sense because it results in one party being held to its bad bargain.

\section{NEW ZEALAND APPELLATE DECISIONS AFTER VECTOR} GAS

\section{A Technix Group Ltd v Fitzroy Engineering Group Ltd}

More recent appellate decisions fortunately seem to apply the commercial common sense yardstick in a more orthodox way. An illustration of the test properly applied is found in both the High Court and Court of Appeal judgments in Technix Group Ltd v Fitzroy Engineering Group Ltd. ${ }^{34}$ In 1992 Fitzroy purchased from Technix an industrial manufacturing and boat-building business in New Plymouth. At the time Fitzroy could not afford to purchase the land on which the business operated and it entered into a lease. In order to give Fitzroy some security, the parties agreed to include an option to purchase clause in the lease. The lease also gave Fitzroy a right of pre-emption if Technix wanted to sell the land in the future or received an offer.

Fitzroy wanted to buy the property and triggered the option to purchase process by giving written notice. The process in the lease required Technix to investigate the cost and procedure involved in subdividing the land. If, following that investigation, Fitzroy wished to proceed it had to formally exercise the option to purchase. After Fitzroy gave written notice to Technix triggering the option to purchase process, Technix received an offer from a "third party" to purchase the property. The third party was a charitable trust associated with a Technix director. Having received the offer,

33 Bank of Nova Scotia v Hellenic Mutual War Risk Assoc (Bermuda) Ltd [1990] 1 QB 818 (CA) at 870.

34 Technix Group Ltd v Fitzroy Engineering Group Ltd [2011] NZCA 17. An application for leave to appeal was dismissed by the Supreme Court: Technix Group Ltd v Fitzroy Engineering Group Ltd [2011] NZSC 57 
Technix purported to trigger the pre-emptive right subclause under the lease, which would require Fitzroy to agree to match the third party's offer within 14 days if it wished to purchase the property.

The issue in the appeal was whether Technix could invoke the pre-emption subclause when Fitzroy had already triggered the option to purchase process. Under the option to purchase provision, Fitzroy had only to purchase the land and premises it used. Under the right of preemption Fitzroy would be required to purchase additional land. The parties also anticipated that the price payable under the option would be less than the third party offer.

The lease provided that the right of pre-emption may be triggered "at any time during the term of the lease". Technix argued there was no justification for going beyond the plain and ordinary meaning of "any time" and therefore that the right of pre-emption could be triggered during periods when the option to purchase process was underway.

As the Court of Appeal concluded, the construction put forward by Technix gave Technix the right to "render valueless" the option granted to Fitzroy. ${ }^{35}$ The Court thought "it impossible that the parties could have intended such a result". ${ }^{36}$ The option to purchase was always going to require a subdivision and the High Court and Court of Appeal noted that the parties must also have understood and accepted that the investigation and subdivision process was always going to take considerably longer than 14 days. ${ }^{37}$ Therefore this was one of the occasions: ${ }^{38}$

... when the plain and ordinary meaning of a contract could not have been what the parties intended,

flouts business common sense and so must yield to the interpretation which does not do so.

The Court of Appeal also had regard to the background to the option to purchase clause and the importance that the parties had attached to it when it was inserted into the agreement. ${ }^{39}$ At that time there was a mutual expectation that it would probably be invoked. This strengthened the Court's conclusions that the parties could not have intended that option to be so easily frustrated by Technix.

The interpretation of the contract argued by Technix, was contrary to the commercial purpose of the option to purchase and the pre-emptive clause. In this sense the interpretation for which Technix contended was contrary to commercial common sense. The Court of Appeal favoured the interpretation most aligned to the purpose of the contract seen through both parties' eyes.

35 Technix Group Ltd v Fitzroy Engineering Group Ltd (CA), above n 34, at [11].

36 At [11].

37 At [13].

38 At [16] citing Antaios, above n 6, at 201; aff'd Investors Compensation Scheme, above n 9, at 913.

39 At [20]-[22]. 


\section{$B$ Firm PI 1 Ltd v Zurich Australian Insurance Ltd}

The Supreme Court returned to the concept of commercial common sense in Firm PI 1 Ltd v Zurich Australian Insurance Ltd. ${ }^{40}$ The case concerned whether the sum insured under the insurance contract for earthquake damage was inclusive or exclusive of the amount payable by the Earthquake Commission (EQC). By a majority, the Court held the sum insured was inclusive of the amount payable by EQC and the insurer was only liable to pay the difference between the sum the insured received from the EQC and the reinstatement value recorded in the contract. This conclusion was reached on the language of the relevant clause read in the context of the entire insurance contract.

The majority (in a judgment delivered by Arnold J) acknowledged the tension between recognising arguments based on commercial absurdity and steering clear of arguments based on bad bargains. Justice Arnold said: ${ }^{41}$

But if consideration of the relevant background forces a court to the conclusion that something has gone wrong with the contractual language, it is not required "to attribute to the parties an intention which they plainly could not have had". ${ }^{42}$ Just as the courts have accepted that understanding the commercial purpose of a commercial contract is relevant to its interpretation, so have they accepted that ... if a particular interpretation produces a commercially absurd result, that may be a reason to read the contract in a different way than the language might suggest. ${ }^{43}$ However, it has also been accepted that a court is not justified in concluding that a contract does not mean what it seems to say simply because the court considers that, so interpreted, the contract is unduly favourable to one party. ${ }^{44}$ There is an obvious tension between these two positions, and it will often be difficult to determine whether particular cases fall within one category or the other. ${ }^{45}$

His Honour went on to consider both, what he described as, the "general structure of the bargain" and "commercial absurdity". ${ }^{46}$ Refreshingly, the majority of the Court recognised "reason

40 Firm PI 1 Ltd v Zurich Australian Insurance Ltd [2014] NZSC 147, [2015] 1 NZLR 432 at [89].

41 At [89].

42 Investors Compensation Scheme, above n 9, at 913 per Lord Hoffmann. See also Chartbrook, above n 17, at [14] per Lord Hoffmann.

43 As occurred, for example, in Investors Compensation Scheme, above n 9; and Chartbrook, above n 17. See also Vector Gas, above n 21, at [8]-[10] per Blanchard J.

44 Chartbrook, above n 17, at [20] per Lord Hoffmann.

45 See the discussion in David McLauchlan "Contract Interpretation in the Supreme Court - Easy Case, Hard Law?" (2010) NZBLQ 229 at 236-238.

46 Firm PI 1, above n 40, at [77] and [88]. 
to be cautious in this area because commercial absurdity tends to lie in the eye of the beholder". ${ }^{47}$ Justice Arnold said:

[91] In addition, those who negotiate commercial contracts will be influenced by a range of considerations in reaching their final bargains. The contracts that emerge from the process of negotiation will reflect accommodations of the parties' varying interests, as they assess them at the time. The reasons underlying the compromises that typically occur in commercial negotiations may not be easily perceived or understood by a court, even if they are exposed as part of the relevant background.

Justice Arnold recognised that at least one of the commercial absurdity arguments was simply the "structure of the bargain" argument in another guise. ${ }^{48} \mathrm{He}$ was not persuaded that the outcome of the alternative interpretation reached the point of commercial absurdity. His Honour preferred to base the conclusions reached on the more conventional analysis of the contractual language and the structure of the bargain. He said: ${ }^{49}$

... in interpreting commercial contracts the court should have regard to their commercial purpose and to the structure of the parties' bargain, to the extent that they can reliably be identified.

The decision in Firm PI 1 shows an emphasis on the more conventional approaches of analysing contractual language and the mutual purpose of the parties' bargain. This is a welcome step towards a more traditional and unassailable application of the commercial common sense yardstick.

This more conventional application of the commercial common sense test in Firm PI 1 has been followed by New Zealand's Court of Appeal. In Body Corporate 341188 v District Court at Auckland the Court of Appeal noted that: ${ }^{50}$

Care is required in concluding that the natural and ordinary meaning of the words read in the relevant context would produce a commercially absurd result, especially in formal documents, which can be expected to have been drafted with the intended meaning of the words being used firmly in mind, and because what may seem commercially absurd to one party is not necessarily absurd from the perspective of another.

One of the reasons the Court gave for preferring the interpretation of the land covenant (and Memorandum of Encumbrance) put forward by the appellant was that the contrary interpretation robbed the document of any purpose and meaning at all. ${ }^{51}$

\author{
47 At [90]. \\ 48 At [97]. \\ 49 At [79]. \\ 50 Body Corporate 341188 v District Court at Auckland [2015] NZCA 393, (2015) 16 NZCPR 667 at [18]. \\ 51 At [50].
}


In Lindsay v Noble Investments Ltd the Court of Appeal referred to Firm PI 1 and went on to say: ${ }^{52}$

Although a commercially absurd interpretation may provide reason to read the contract in a different way than the language might suggest, that does not mean the court can conclude the contract does not mean what it seems to say simply because the court considers it is unduly favourable to one party.

Finally, in New Zealand Carbon Farming Ltd v Mighty River Power Ltd the Court of Appeal accepted the cautions about evoking commercial common sense set out by Lord Neuberger SCJ in Arnold v Britton. ${ }^{53}$

\section{UNITED KINGDOM CASES}

Before the United Kingdom Supreme Court's judgment in Arnold v Britton the leading United Kingdom case on commercial common sense was Rainy Sky SA v Kookmin Bank. ${ }^{54}$ The case concerned a dispute between a bank and six ship owning companies who had commissioned a vessel from a ship builder. It was a condition of the ship building contracts that the ship builder would provide each with a bond, backed by a bank, so that if there was a default the buyers would be entitled to repayment of any instalments they had already paid.

The ship builder became insolvent and failed to refund the instalments paid pre-delivery. The buyers claimed against the bank under the bonds. The drafting of the bonds did not match the drafting of the ship building contracts and did not provide for refund of the instalments paid if the ship builder became insolvent. Lord Justice Patten, in the Court of Appeal, had felt constrained to give effect to the natural meaning of the words used in the bond unless an extreme (or absurd, or irrational) result was produced. ${ }^{55} \mathrm{He}$, therefore, decided the ship owners were not entitled to a refund of their pre-delivery payments.

Lord Clarke SCJ, delivering the single judgment of the Supreme Court, applied the concept of commercial common sense to prefer the interpretation that, in his view, was more likely to reflect the parties' intentions. He held the ship owners were entitled to repayment of the instalments. Lord Clarke SCJ referred to the judgment of Longmore LJ in Barclays Bank Plc v HHY Luxembourg SARL: $: 56$

52 Lindsay $v$ Noble Investments Ltd [2015] NZCA 588 at [16].

53 New Zealand Carbon Farming Ltd v Mighty River Power Ltd [2015] NZCA 605 at [103]-[104]. See also Arnold v Britton, above $\mathrm{n} 1$.

54 Rainy Sky, above n 4

55 At [18].

56 Barclays Bank Plc v HHY Luxembourg SARL [2010] EWCA Civ 1248, [2011] 1 BCLC 336 at [26]. 
If a clause is capable of two meanings, as on any view this clause is, it is quite possible that neither meaning will flout common sense. In such circumstances, it is much more appropriate to adopt the more, rather than the less, commercial construction.

The trial Judge had found that "the most likely reason" why the security of an advanced payment bond would be needed was in the event the ship builder became insolvent. ${ }^{57}$ In argument, Kookmin Bank had been unable to advance any commercial reason for the bonds not to cover the ship builder's insolvency. The contracts, looked at as a whole, placed a lot of emphasis on the need for an immediate refund in the event of insolvency. Therefore it made most commercial sense for the repayment obligations in the bond to be interpreted consistently with the repayment obligations in the ship building contracts and to provide for repayment of instalments paid in the event of the ship builder's insolvency. ${ }^{58}$ Lord Clarke SCJ thought that if the parties had intended the "surprising and uncommercial" result that insolvency could not trigger repayment, the documents would no doubt have spelt this out clearly and they did not. ${ }^{59}$

The United Kingdom Supreme Court determined which interpretation made more commercial sense by reviewing the overall purpose and other provisions of the contract.

That brings us to the decision of the United Kingdom Supreme Court in June 2015 in Arnold v Britton. ${ }^{60}$ The case concerned the interpretation of service charge contribution clauses in the leases of a number of chalets in a caravan park in New South Wales. Lord Neuberger SCJ delivered the majority judgment. He emphasised seven general principles in relation to interpretation of contractual provisions. Three related to the Court's use of commercial common sense. They are worth repeating in full and were:

[17] First, the reliance placed in some cases on commercial common sense and surrounding circumstances (eg in Chartbrook at [16]-[26]) should not be invoked to undervalue the importance of the language of the provision which is to be construed. The exercise of interpreting a provision involves identifying what the parties meant through the eyes of a reasonable reader, and, save perhaps in a very unusual case, that meaning is most obviously to be gleaned from the language of the provision. Unlike commercial common sense and the surrounding circumstances, the parties have control over the language they use in a contract. And, again save perhaps in a very unusual case, the parties must have been specifically focussing on the issue covered by the provision when agreeing the wording of that provision.

57 Rainy Sky, above n 4, at [41].

58 At [44]-[45].

59 At [41].

60 Arnold v Britton, above n 1. 
[19] The third point I should mention is that commercial common sense is not to be invoked retrospectively. The mere fact that a contractual arrangement, if interpreted according to its natural language, has worked out badly, or even disastrously, for one of the parties is not a reason for departing from the natural language. Commercial common sense is only relevant to the extent of how matters would or could have been perceived by the parties, or by reasonable people in the position of the parties, as at the date that the contract was made....

[20] Fourthly, while commercial common sense is a very important factor to take into account when interpreting a contract, a court should be very slow to reject the natural meaning of a provision as correct simply because it appears to be a very imprudent term for one of the parties to have agreed, even ignoring the benefit of wisdom of hindsight. The purpose of interpretation is to identify what the parties have agreed, not what the court thinks that they should have agreed. Experience shows that it is by no means unknown for people to enter into arrangements which are ill-advised, even ignoring the benefit of wisdom of hindsight, and it is not the function of a court when interpreting an agreement to relieve a party from the consequences of his imprudence or poor advice. Accordingly, when interpreting a contract a judge should avoid re-writing it in an attempt to assist an unwise party or to penalise an astute party.

The reader will by now realise that Lord Neuberger SCJ's fourth principle expresses the premise of this article far more eloquently than the author does.

The landlord contended that the effect of the provisions in the lease was that there was a fixed annual service charge for the first year, increasing each year by 10 per cent on a compound basis. The lessees' argued for an alternative interpretation. One of their primary contentions was that the lessor's construction resulted in such an increasingly absurdly high annual service charge in the latter years of each lease that it could not be correct.

Lord Neuberger SCJ was not persuaded by arguments based on the assertion that the lessor's interpretation had come to have unattractive consequences for the lessees. In accepting the lessor's construction, primarily because it was more consistent with the express language of the contract, Lord Neuberger SCJ also said:

[37] ... People enter into all sorts of contracts on the basis of hopes, expectations and assessments which no professional expert would consider prudent, let alone feel able to "predict with accuracy". I have little doubt that many fortunes have been both made and lost (and sometimes both) by someone entering into such a contract.

Writing extrajudically Lord Neuberger has said: ${ }^{61}$

61 Lord Neuberger "The Impact of Pre- and Post-Contractual Conduct on Contractual Interpretation" (paper presented to Banking Services and Finance Law Association Conference, Queenstown, New Zealand, 11 August 2014) at [20]. 
We have to be very wary of relying on commercial common sense. First, a judge's idea of commercial common sense may be thought by some to be about as reliable as a businessman's idea of legal principle. Secondly, the judicial view of commercial common sense in a particular case is almost bound to be influenced by the facts as they have transpired since the contract, which should plainly be irrelevant to the exercise of interpretation.

This statement has been described as somewhat surprising, particularly since judges are called upon to make judgments concerning other broad notions, for example good faith and unconscionability. ${ }^{62}$ However, commercial common sense is not the same as good faith or unconscionability. Determining arguments about good faith and unconscionability is most likely to primarily involve issues of justice and fairness, which are well within the range of topics a judge should be expected to decide. Outside the limits of the mutual purpose of parties to a contract, commercial common sense is, as titled, dependent on the commercial circumstances, goals, knowledge, experience and acumen of the parties. It is not something a judge is necessarily best placed to decide.

There are risks in encouraging parties to attempt to persuade a judge towards a particular interpretation by virtue of the commercial common sense test. It is conceivable that parties could call expert evidence to establish the commercial common sense of a particular transaction. Alternatively a party may seek to admit extrinsic evidence around the commercial common sense of the transaction, in addition to its context and surrounding facts.

Any use of the commercial common sense test that encourages judges to rank commercial decisions or parties to expand the extrinsic evidence that can be called in aid of a particular contractual interpretation ought to be avoided.

It has been suggested that the more recent decisions signal a shift in the approach to interpretation of contracts generally and a return to a more conservative approach under which disputes are resolved primarily on the basis of textual analysis with limited resort to external context, including considerations of commercial common sense. ${ }^{63}$

The trend does appear to be towards a more conservative approach to interpretation of contracts. To the extent that conservative approach gives rise to greater certainly and predictability in the law, that is desirable. However, the New Zealand courts at least, still show a willingness to look outside the particular document which is the subject of the dispute and to consider the commercial purpose of the parties to determine the proper interpretation. ${ }^{64}$

62 McLauchlan, above n 10, at 432.

63 At 432 .

64 See for example Body Corporate 341188, above n 50. 
In relation to the concept of commercial common sense there does seem to be a rejection of the suggestion that a court may interpret a contract in such a way as to prevent it being unduly favourable to one party. This was never the way in which the commercial common sense test should have been used. A shift away from this is a welcome shift.

\section{CONCLUSION}

Applied properly the commercial common sense touchstone for interpretation of contracts is unexceptional. If an interpretation frustrates the parties' mutual commercial purpose, an alternative interpretation is more likely to be correct. However, the test ought not be applied simply on the basis that a particular interpretation results in one contracting party being bound by a bad bargain. A court is not the best judge of what constitutes a bad bargain and its task is not to relieve a contracting party of the consequences of entering into one. The courts appear to be accepting of this in more recent decisions. 